\title{
Leaf anatomy and carbon isotope composition in Coffea species related to photosynthetic pathway
}

\author{
Maria Luiza Carvalho Carelli ${ }^{1 *}$, Rachel Benetti Queiroz-Voltan² ${ }^{2}$ Joel Irineu Fahl ${ }^{1}$ \\ and Paulo César Ocheuze Trivelin ${ }^{3}$
}

\begin{abstract}
${ }^{1}$ Centro de Pesquisa e Desenvolvimento de Ecofisiologia e Biofísica, Instituto Agronômico de Campinas, CP 28, CEP 13001-970 Campinas, SP, Brasil; ${ }^{2}$ Núcleo de Pesquisa e Desenvolvimento do Jardim Botânico/CEC, Instituto Agronômico de Campinas; ${ }^{3}$ Centro de Energia Nuclear na Agricultura, USP, CP 96, CEP 13400-970 Piracicaba, SP, Brasil; *Corresponding author: carelli@iac.sp.gov.br Received: 05/08/2002, Accepted: 28/01/2003
\end{abstract}

Possible presence of vascular bundle sheath cells and its relation to photosynthetic pathway, leaf anatomy and carbon isotope composition $\left(\delta^{13} \mathrm{C}\right)$ were examined in six species of genus Coffea: C. arabica (cvs. Catuaí Vermelho, Mundo Novo, Bourbon Vermelho and Icatu Amarelo), C. canephora (cvs. Apoatã and Guarini), C. liberica, C. dewevrei, C. salvatrix and $C$. stenophylla. In all genotypes, the vascular bundle was surrounded by a layer of cells with numerous chloroplasts in a centrifugal position. Visually no differences could be seen between the spongy parenchyma cells and the bundle sheath cells, neither in size nor in chloroplast number. The leaf $\delta^{13} \mathrm{C}$ values ranged between a maximum of - $26.2 \%$ in C. salvatrix and a minimum of $-29.7 \%$ in C. liberica. A strong correlation $(\mathrm{r}=0.972, p=0.001)$ between $\delta^{13} \mathrm{C}$ and anatomical characteristics was observed in coffee species. C. salvatrix exhibited the highest $\delta^{13} \mathrm{C}$ values and the most compact mesophyll, with more palisade and spongy parenchyma cells in contact with the vascular bundle sheath.

Keywords: bundle sheath cells, Coffea, leaf anatomy, leaf carbon isotope composition.

Anatomia foliar e composição isotópica do carbono relacionadas com a via fotossintética em espécies de Coffea: Neste trabalho foi examinada a possível existência de uma bainha de células nos feixes vasculares relacionada com a via fotossintética, a anatomia foliar e a composição isotópica do carbono $\left(\delta^{13} \mathrm{C}\right)$ em seis espécies do gênero Coffea: $C$. arabica (cvs. Catuaí Vermelho, Mundo Novo, Bourbon Vermelho and Icatu Amarelo), C. canephora (cvs. Apoatã and Guarini), C. liberica, C. dewevrei, C. salvatrix and C. stenophylla. Em todos os genótipos os feixes vasculares estavam envolvidos por uma camada de células com numerosos cloroplastos localizados na posição centrífuga. Visualmente, não foram observadas diferenças entre as células da bainha vascular e as do parênquima esponjoso, tanto no número como no tamanho dos cloroplastos. Os valores de $\delta^{13} \mathrm{C}$ das folhas variaram entre um máximo de - 26,2 \%o em C. salvatrix e um mínimo de -29,7 \% em C. liberica. Foi observada uma alta correlação $(\mathrm{r}=0,972, p=0,001)$ entre os valores de $\delta^{13} \mathrm{C}$ e as características anatômicas das folhas. C. salvatrix apresentou o mais alto valor de $\delta^{13} \mathrm{C}$ e o maior número de células do mesófilo em contato com as células da bainha vascular.

Palavras-chave: anatomia foliar, bainha dos feixes vasculares, Coffea, composição isotópica do carbono das folhas.

\section{INTRODUCTION}

Plants with $\mathrm{C}_{4}$ photosynthesis have a specialized leaf biochemistry, physiology and anatomy required for their photosynthetic $\mathrm{CO}_{2}$ metabolism, the Hatch-Slack pathway, which efficiently reduces photorespiration to negligible levels, thus increasing the potential for $\mathrm{CO}_{2}$ assimilation (Black, 1973; Hatch, 1987). The specialized anatomy is characterized by well-developed vascular bundle sheath cells containing large quantities of chloroplasts and others organelles (Black and Mollenhauer, 1971). Kranz anatomy is under multigenic control, thus, species might exist that are in the process of evolving toward $\mathrm{C}_{4}$ photosynthesis, with intermediate characteristics between those of $\mathrm{C}_{3}$ and $\mathrm{C}_{4}$ plants in what concerns anatomy, physiology or 
biochemistry (Edwards and Ku, 1987; Larcher, 1995). A number of naturally occurring plant species, with photosynthetic characteristics intermediate between $\mathrm{C}_{3}$ and $\mathrm{C}_{4}$ have been identified (Edwards and $\mathrm{Ku}, 1987$ ). Most of the intermediate have in common an anatomy between that of non-Kranz and Kranz and belong to genera that are known to contain both $\mathrm{C}_{3}$ and $\mathrm{C}_{4}$ species.

Coffee species exhibit all the physiological and biochemical characteristics of plants with predominantly $\mathrm{C}_{3}$ photosynthetic pathways: ${ }^{14} \mathrm{CO}_{2}$ is incorporated first into 3-C phosphorylated compounds (Nunes et al., 1973), the $\mathrm{CO}_{2}$ compensation point lies in the range of 50-100 vpm at $20-25{ }^{\circ} \mathrm{C}$ (Cannell, 1987), the net photosynthetic rates are depressed by increased $\mathrm{O}_{2}$ partial pressure (Sondahl et al., 1976) and show estimated high photorespiration rate (Guedes and Nunes, 1978). The maximum net photosynthetic rates for coffee plants are around $7-11 \mu \mathrm{mol} \mathrm{CO} \mathrm{m}^{-2} \cdot \mathrm{s}^{-1}$ which is much lower than 15-25 $\mu \mathrm{mol} \mathrm{CO} \mathrm{Cm}^{-2} \cdot \mathrm{s}^{-1}$, commonly recorded for leaves of $\mathrm{C}_{3}$ crop field (Cannell, 1987). In addition, the saturating irradiance for coffee leaf photosynthesis is low, around 600-750 $\mu \mathrm{mol} . \mathrm{m}^{-2} . \mathrm{s}^{-1}$ for sun leaves and 300-400 $\mu \mathrm{mol} . \mathrm{m}^{-2} . \mathrm{s}^{-1}$ for shade leaves (Yamaguchi and Friend, 1979; Fahl et al., 1994; Ramalho et al., 2000), but under Brazilian conditions, where coffee is cultivated without shading, the plants have to endure irradiance as high as $2000 \mu \mathrm{mol} . \mathrm{m}^{-2} \cdot \mathrm{s}^{-1}$.

Despite the classification as $\mathrm{C}_{3}$, coffee plants may display some interesting features concerning leaf anatomy and photosynthetic rates. Dedecca (1957) reported the existence of a layer of parenchyma cells around the vascular bundle for C.arabica cv. typica, but did not mention the presence of chloroplasts. More recently, it was observed that C. arabica cv. Caturra and C. canephora presents the same cell layer with chloroplasts apparently similar to those present in the mesophyll cells, what lead to the hypothesis that such coffee genotypes could possess a photosynthetic pathway somewhat different from that of typical $\mathrm{C}_{3}$ species (Castaño and Dávila, 1974). In fact, recently it was shown that $C$. arabica genotypes had a higher phosphoenolpyruvate (PEP) carboxylase activity than typical $\mathrm{C}_{3}$ plant (Lopes et al., 2000). On the other hand, Sondahl et al. (1976) suggested that photorespiration has a more significant effect on photosynthetic rate in $C$. canephora than in C. arabica. When the $\mathrm{O}_{2}$ concentration was lowered from 20 to $5 \%$, the net photosynthetic rate increased by $29 \%$ for C. canephora cv. Guarini, whereas in C. arabica cv. Catuaí there was no significant change (Sondahl et al., 1976). In the later cultivar, it was reported that exposure to full sunlight (Carelli et al.,1999) and drought conditions (Meinzer et al., 1990) decrease carbon isotope discrimination $(\Delta)$ in leaves.

The principal basis for discrimination against ${ }^{13} \mathrm{CO}_{2}$ in $\mathrm{C}_{3}$ plants lies in the enzyme ribulose-1,5-bisphosphate carboxylase/oxygenase (rubisco), which prefers ${ }^{12} \mathrm{C}$. Rubisco discriminates much more against ${ }^{13} \mathrm{C}(-28 \%)$ than PEP carboxylase (-9\%), which uses $\mathrm{HCO}_{3}{ }^{-}$. Since in $\mathrm{C}_{4}$ plants there is a small additional discrimination due to resistance of diffusion, the carbon isotope composition $\left(\delta^{13} \mathrm{C}\right)$ values will range from -10 to $-18 \%$ (mean -13 $\%$ ), while in terrestrial $\mathrm{C}_{3}$ plants it will range from -23 to -36 \%o (mean 27 \%) (Edwards and Ku, 1987; Larcher, 1995). Carbon isotope discrimination in $C_{3}$ plants is positively correlated with the ratio of intercellular to atmospheric partial $\mathrm{CO}_{2}$ pressure $\left(\mathrm{p}_{\mathrm{i}} / \mathrm{p}_{\mathrm{a}}\right)$, a parameter which reflects the balance between consumption of $\mathrm{CO}_{2}$ by photosynthetic activity and supply of $\mathrm{CO}_{2}$ through stomatal diffusion (Farquhar et al., 1982; 1989).

Isotopic screening has been a simple test for determining the photosynthetic pathway when it is unknown; the results have provided a broad base of distribution of photosynthetic groups and ecological zones (Farquhar et al., 1989). Among more than 100 species of Coffea, leaf anatomy concerning the presence of vascular bundle sheaths, and $\delta^{13} \mathrm{C}$, to our knowledge, was investigated only in C. arabica and C. canephora. In the present work leaf anatomy and $\delta{ }^{13} \mathrm{C}$ were examined in species of four subsections of the genus Coffea in order to investigate the presence of vascular bundle sheath cells in relation to photosynthetic pathway.

\section{MATERIAL AND METHODS}

Plant material: Six species, listed in table 1, were selected as representatives of four subsections of genus Coffea: Erythrocoffea, Pachycoffea, Melanocoffea and Mozambicoffea, according to the classification of Chevalier (1947). The coffee genotypes from C. arabica (cvs. Catuaí Vermelho, Mundo Novo, Bourbon Vermelho and Icatu Amarelo) and C. canephora (cvs. Apoatã and Guarini) were obtained by the Instituto Agronômico de Campinas, SP, Brazil, through genetic breeding. $C$. liberica, C. dewevrei, C. salvatrix and C. stenophylla are wild species. 
The studies were carried out with leaf material (third leaf pair) collected on the living collections of the germoplasm bank of Instituto Agronômico, Campinas (lat. $22^{\circ} 53^{\prime} \mathrm{S}$, long. $47^{\circ} 05^{\prime} \mathrm{W}$, elev. $670 \mathrm{~m}$ ), in field grown plants, under full sunlight. The climate of the region is characterized by a hot and humid summer and a moderate cold and dry winter, with annual dry season extending from May to August, annual mean temperature of $20.7^{\circ} \mathrm{C}$ and annual precipitation of $1,300 \mathrm{~mm}$. Leaf samples were collected in March, at the end of humid season.

Leaf anatomy: Samples of approximately $0.25 \mathrm{~cm}^{2}$ of tissue were cut from mature leaves (third leaf pair) of five trees for each genotype. Leaf material was fixed in FAA 50, a mixture of formaldehyde - acetic acid - $50 \%$ ethanol (Johansen, 1940), dehydrated in a graded ethanol series and then embedded in paraffin wax. The leaf cross section were cut at $13 \mu \mathrm{m}$ (thickness) on a microtome rotative and stained in safranin-alcian blue. The samples were examined and photographed using the photomicroscope Jenaval.

The number of palisade and spongy parenchyma cells in direct/indirect contact with the bundle sheath cells was determined in a constant area of 30 cross sections for each six genotypes (C. arabica cv. Icatu Amarelo, C. canephora cv. Apoatã, C. canephora cv. Guarini, C. dewevrei, C. salvatrix and $C$. stenophylla). The data was subjected to a variance analysis and a comparison of means carried out using Tukey's test at $p<0.05$.

Carbon isotope composition: Carbon isotope composition was determined in mature leaves (third leaf pair) of branches in the middle canopy layer. For each genetic material, five replicates of oven-dried leaves were finely ground. Samples were combusted (Swerhone et al., 1991) and the relative abundance of ${ }^{13} \mathrm{C}$ and ${ }^{12} \mathrm{C}$ in the $\mathrm{CO}_{2}$ produced was determined by mass spectrometry. Analyses were performed at the Centro de Energia Nuclear na Agricultura, Universidade de São Paulo, Piracicaba, SP, Brazil. Carbon isotope composition was expressed as ${ }^{13} \mathrm{C} /$ ${ }^{12} \mathrm{C}$ ratio $\left(\delta^{13} \mathrm{C}\right)$ relative to that of Pee Dee belemnite standard with a precision of $\pm 0.20 \%$. The carbon isotope composition data was subjected to a variance analysis and a comparison of means carried out using Tukey's test at $p<0.05$.

\section{RESULTS}

The mesophyll tissue of Coffea species and cultivars is differentiated into upper palisade parenchyma and lower spongy parenchyma as found in dicotyledonous $\mathrm{C}_{3}$ plants (figures 1-3). The vascular bundles, in all genetic material examined, were surrounded by a distinctive layer of cells with numerous chloroplasts in a centrifugal position. Surrounding the bundle sheath cells were palisade parenchyma below the adaxial epidermis and spongy parenchyma above the abaxial epidermis. However, there is not a uniform layer of mesophyll cells surrounding the bundle sheath. Visually no differences were noted between the spongy parenchyma cells and the bundle sheath cells, neither in size nor in chloroplast number. In coffee species a higher proportion of leaf chloroplasts were in palisade parenchyma.

Leaf tissue $\delta^{13} \mathrm{C}$ changed significantly between the subsections of Coffea but there were no differences within each subsection, excepting for C. arabica cv. Icatu Amarelo and for $C$. canephora cv. Guarini. The values ranged between a maximum of $-26.2 \%$ in $C$. salvatrix and a minimum of $-29.7 \%$ in C. liberica (table 1 ).

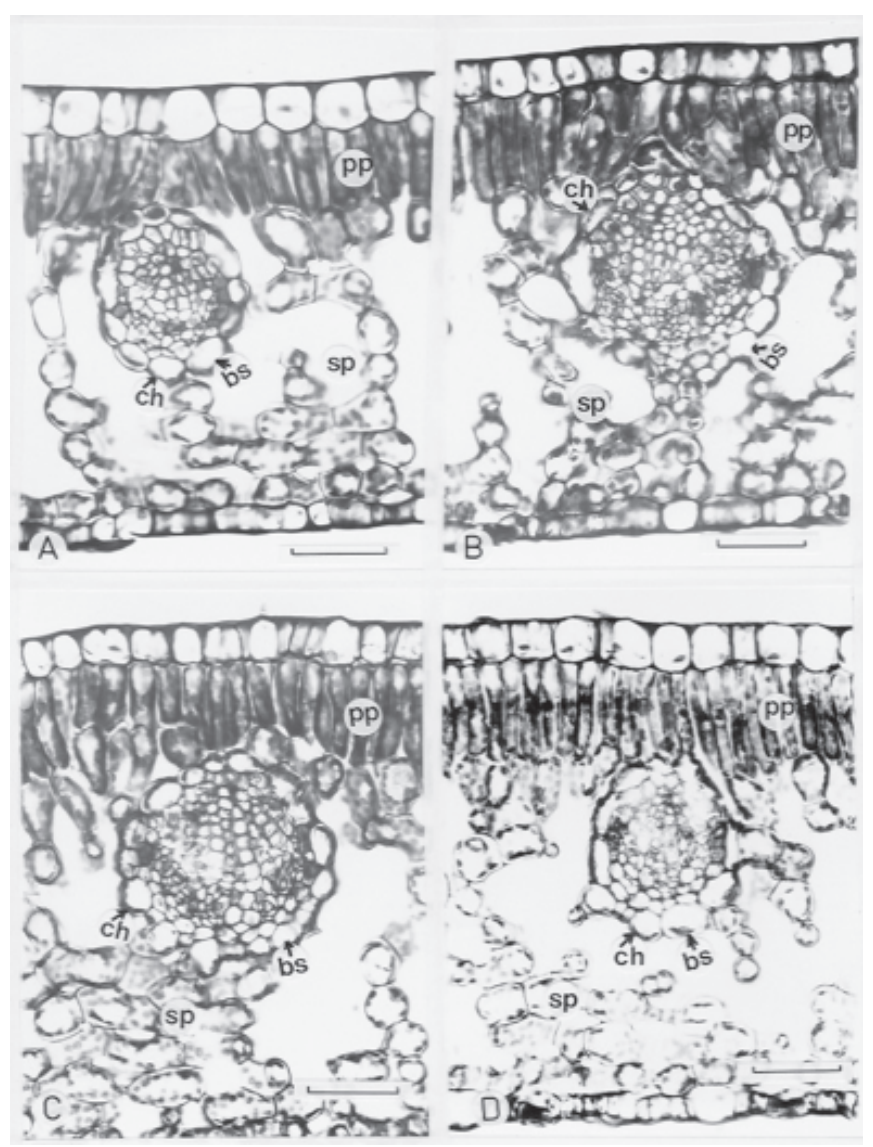

Figure 1. Light micrographs of leaf transverse sections of C. arabica cultivars. (A) Bourbon vermelho; (B) Mundo Novo; (C) Catuaí Vermelho; (D) Icatu Amarelo. bs, bundle sheath cell; pp, palisade parenchyma; sp, spongy parenchyma; ch, chloroplast. Bar $=50 \mu \mathrm{m}$. 


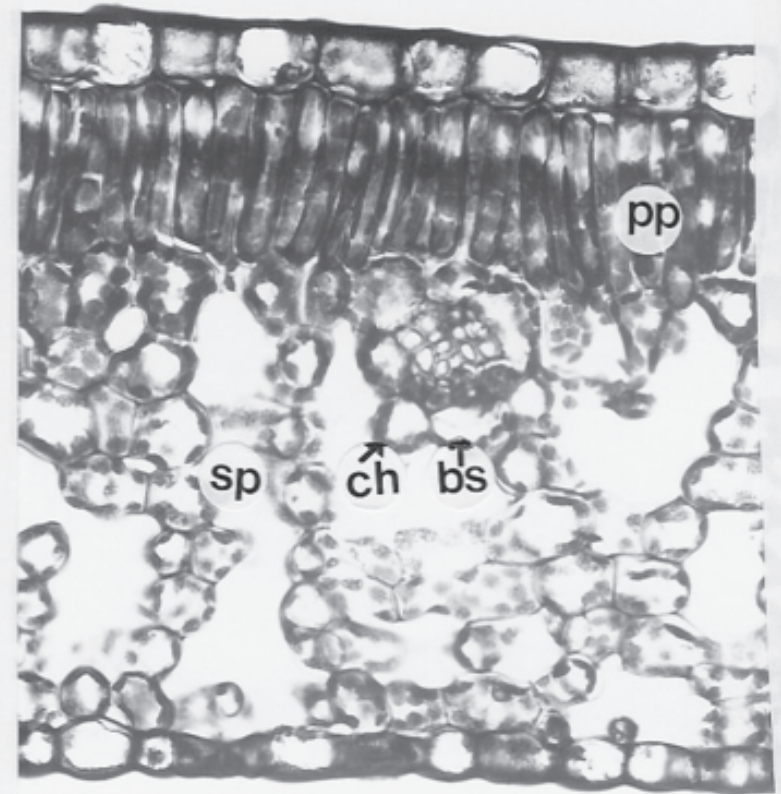

A

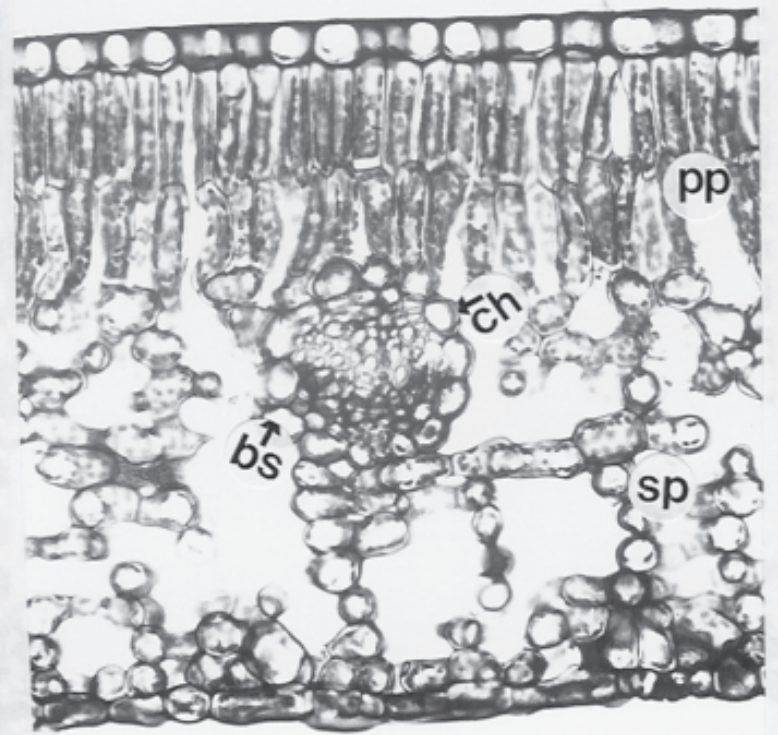

B

Figure 2. Light micrographs of leaf transverse sections of C. canephora cultivars. (A) Apoatã; (B) Guarini. bs, bundle sheath cell; pp, palisade parenchyma; sp, spongy parenchyma; ch, chloroplast. Bar $=50 \mu \mathrm{m}$.

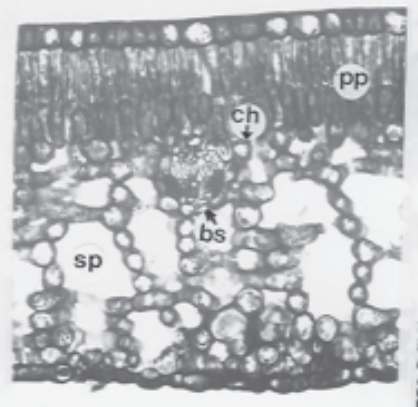

A

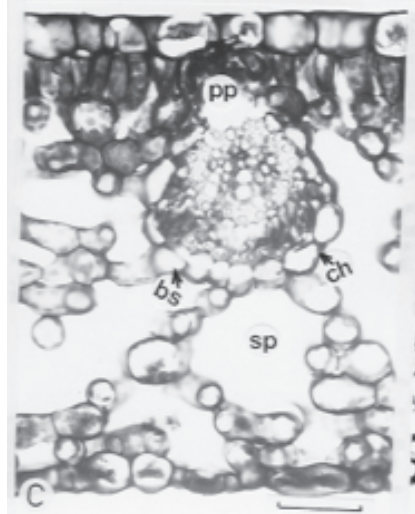

Figure 3. Light micrographs of leaf transverse sections of coffee species: (A) C. dewevrei; (B). C. salvatrix; (C) C. liberica; (D) C. stenophylla. bs, bundle sheath cell; pp, palisade parenchyma; sp, spongy parenchyma; ch, chloroplast. $\mathrm{Bar}=50 \mu \mathrm{m}$.
The number of mesophyll cells in contact with the bundle sheath cells was significantly different among coffee species (table 1). These differences were mainly due to the number of spongy parenchyma cells, since there was lower variation in the pallisade parenchyma. C. salvatrix showed the most compact mesophyll with more cells in contact with the bundle sheath cells, followed by $C$. stenophylla, C. canephora, C. arabica and C. dewevrei.

A strong correlation $(\mathrm{r}=0.972, p=0.001)$ between leaf tissue $\delta^{13} \mathrm{C}$ and the anatomical characteristics was observed in coffee species. C. salvatrix showed the highest $\delta^{13} \mathrm{C}$ value and the highest number of mesophyll cells in direct contact with the vascular bundle sheath cells (table 1 , figure $3 \mathrm{~B})$.

\section{DISCUSSION}

As previously described for $C$. arabica and $C$. canephora (Castaño and Dávila, 1974) in the present paper the vascular bundle in all the coffee species examined were surrounded by a layer of chlorenchymatous cells. However, the mesophyll is not in a concentric ring around the bundle sheath cells as in a typical dicotyledonous $\mathrm{C}_{4}$ leaves (Holaday et al., 1984). Similar chlorenchymatous bundle sheath cells as in coffee were shown in the dicotyledons plant cassava (Manihot esculenta) by Edward et al. (1990), 
who considered this type of leaf anatomy unfavourable for performing as either a $\mathrm{C}_{3}-\mathrm{C}_{4}$ intermediate or as a $\mathrm{C}_{4}$ plant, since the bundle sheath cells are spatially separated from the layer of palisade cells. This leaf structure does not provide the substantial intercellular transport required for partial function of $\mathrm{C}_{4}$ photosynthesis (Edwards and $\mathrm{Ku}$, 1987). Compared to cassava, apparently, the bundle sheath cells in some coffee species exhibit higher direct contact with cells of palisade parenchyma, suggesting higher intercellular transport. However, this does not mean that coffee shows a $\mathrm{C}_{3}-\mathrm{C}_{4}$ intermediate anatomy nor a rudimentary $\mathrm{C}_{4}$ pathway. Furthermore, several studies with C. arabica plants suggested that this specie exhibit biochemical and physiological characteristics of a typical $\mathrm{C}_{3}$ plant (see introduction).

The pathway of carbon assimilation can alter with adaptation to irradiance, as showed in Flaveria brownii (Nelson and Langdale, 1992) or with a shift from one habitat to another. The genus Coffea evolved as evergreen understorey (shaded) shrubs or trees in African tropical forests at elevations between 1,700 and 2,000 m, but in Brazil the wild coffee species are grown under full sunlight. In addition, the actual Brazilian cultivars were obtained after genetic selection under full sunlight. However, no differences in the anatomical characteristics of bundle sheath cells among wild coffee species and breeding cultivars were observed in the present paper.

Despite of some significant differences among the species of the four subsections (table 1), the obtained $\delta^{13} \mathrm{C}$ values were in the range of what could be expected for a $\mathrm{C}_{3}$ plant (typically between -23 to $-36 \%$ ), since the values ranged between a maximum of $-26.2 \%$ (C. salvatrix) and a minimum of $-29.7 \%$ (C. liberica), and were quite far away from the expected values of $\mathrm{C}_{4}$ plants, that are between -10 and $-18 \%$ (Edwards and $\mathrm{Ku}, 1987$; Larcher, 1995).

The magnitude of $\delta^{13} \mathrm{C}$ in $\mathrm{C}_{3}$ plants is largely determined by the ratio of intercellular to atmospheric partial $\mathrm{CO}_{2}$ pressure $\left(\mathrm{p}_{\mathrm{i}} / \mathrm{p}_{\mathrm{a}}\right)$ prevailing when the carbon is assimilated (Farquhar et al., 1982). This ratio represents a balance between the rates of inward $\mathrm{CO}_{2}$ diffusion, controlled by stomatal conductance, and $\mathrm{CO}_{2}$ assimilation determined by photosynthesis (A/g) (Farquhar et al., 1982). Changes in leaf tissue $\Delta$ (and consequently $\delta^{13} \mathrm{C}$ ) in coffee plants are strongly correlated with pi/pa (Meinzer et al., 1990; Carelli et al., 1999). Therefore, the variation in $\delta^{13} \mathrm{C}$ among coffee species, showed in the present study, may be related to the differences in gas exchanges rather than to different photosynthetic pathway.

Table 1. Carbon isotope composition $\left(\delta^{13} \mathrm{C}\right)$ and cells number of palisade parenchyma (PP), spongy parenchyma (SP) and mesophyll (M) in contact with the bundle sheath cells, in leaves of Coffea species.

\begin{tabular}{|c|c|c|c|c|}
\hline \multirow{2}{*}{ Genotype } & \multirow{2}{*}{$\delta^{13} \mathrm{C}\left(\%_{\mathrm{oo}}\right)^{\mathrm{a}}$} & \multicolumn{3}{|c|}{ Cell number } \\
\hline & & PP & SP & M \\
\hline \multicolumn{5}{|l|}{ Erythrocoffea } \\
\hline C. arabica cv. Catuaí Vermelho & $-27.8 b$ & - & - & - \\
\hline C. arabica cv. Mundo Novo & $-27.7 b$ & - & - & - \\
\hline C. arabica cv. Bourbon Vermelho & $-27.6 b$ & - & - & - \\
\hline C. arabica cv. Icatu Amarelo & $-28.6 \mathrm{c}$ & $26.2 \mathrm{c}$ & $18.6 \mathrm{a}$ & $44.8 \mathrm{~b}$ \\
\hline C. canephora cv. Apoatã & $-27.6 b$ & $24.1 \mathrm{ab}$ & $25.1 \mathrm{~b}$ & $49.2 \mathrm{bc}$ \\
\hline C. canephora cv. Guarini & $-28.7 \mathrm{c}$ & $24.2 \mathrm{ab}$ & $21.5 \mathrm{ab}$ & $45.6 \mathrm{~b}$ \\
\hline \multicolumn{5}{|l|}{ Pachycoffea } \\
\hline C. liberica & $-29.7 d$ & - & - & - \\
\hline C. dewevrei & $-29.5 d$ & $23.4 \mathrm{a}$ & $16.7 \mathrm{a}$ & $40.1 \mathrm{a}$ \\
\hline \multicolumn{5}{|l|}{ Mozambicoffea } \\
\hline C. salvatrix & $-26.2 \mathrm{a}$ & $25.6 \mathrm{bc}$ & $38.2 \mathrm{~d}$ & $63.7 \mathrm{~d}$ \\
\hline \multicolumn{5}{|l|}{ Melanocoffea } \\
\hline C. stenophylla & $-27.7 b$ & $23.0 \mathrm{a}$ & $31.1 \mathrm{c}$ & $54.0 \mathrm{c}$ \\
\hline
\end{tabular}

${ }^{a}$ Numbers followed by the same letter in the column do not differ significantly at $p<0.05$ (Tukey's test). 
A strong correlation between $\delta^{13} \mathrm{C}$ and anatomical characteristics was observed in coffee species. C. salvatrix exhibited the highest $\delta^{13} \mathrm{C}$ values and the most compact mesophyll, with more cells in contact with the vascular bundle sheath. On the other extreme, $C$. dewevrei showed the lowest $\delta^{13} \mathrm{C}$ value and less mesophyll cells around the vascular bundle sheath cells. Previous studies reported that the increase in mesophyll cells density of sun leaves, compared with shade leaves on the same coffee specie, was associated with increases in photosynthetic rate (Fahl, 1989; Voltan et al., 1992; Fahl et al., 1994). Furthermore, it was suggested that higher leaf $\delta^{13} \mathrm{C}$ values, observed in sun grown coffee species compared with the shaded ones, could be due to higher photosynthetic efficiency (Carelli et al., 1999). Therefore, the explanation for the correlation between leaf $\delta^{13} \mathrm{C}$ values and the anatomical characteristics, observed in coffee species, may be related to the photosynthetic efficiency rather than the presence of a rudimentary $\mathrm{C} 4$ pathway.

\section{REFERENCES}

Black Jr CC (1973) Photosynthetic carbon fixation in relation to net $\mathrm{CO}_{2}$ uptake. Annu. Rev. Plant Physiol. 24:253-286.

Black Jr CC, Mollenhauer HH (1971) Structure and distribution of chloroplasts and other organelles in leaves with various rates of photosynthesis. Plant Physiol. 47:15-23.

Cannel MGR (1987) Physiology of the coffee crop. In: Clifford MN, Wilson KC. (eds.), Coffee: Botany, Biochemistry and production of beans and beverage. pp.108-134. Croom Helm, London.

Carelli MLC, Fahl JI, Trivelin PCO, Queiroz-Voltan RB (1999) Carbon isotope discrimination and gas exchange in Coffea species grown under different irradiance regimes. Rev. Bras. Fisiol. Veg. 11:63-68.

Castaño FJO, Dávila CC (1974) Caracteristicas anatomicas de las hojas y su relación con el posible ciclo fotosintético en café. Cenicafé 25:104-112.

Chevalier A (1947) Les caféiers du globe: III. Sistématique des caféirs et faux-caféiers maladies et insectes nuisibles. In: Encyclopedie Biologique. v.28, 352pp. Paul Lechevalier, Paris.

Dedecca DM (1957) Anatomia e desenvolvimento ontogênico de Coffea arabica L. cv. Typica Cramer. Bragantia 16:315-366.

Edwards GE, Ku MSB (1987) Biochemistry of $\mathrm{C}_{3}-\mathrm{C}_{4}$ intermediates. In: Hatch M.D, Boardman NK (eds), Biochemistry of Plants: Photosynthesis. vol. 14, pp.275-325. Academic Press, San Diego.

Edwards GE, Sheta E, Moore BD, Dai Z, Franceschi VR, Cheng S, Lin C, Ku M (1990) Photosynthetic characteristics of cassava (Manihot esculenta Crantz), a $\mathrm{C}_{3}$ species with chlorenchymatous bundle sheath cells. Plant Cell Physiol. 31:1199-1206.

Fahl JI (1989) Influência da irradiância e do nitrogênio na fotossíntese e no crescimento de plantas de café (Coffea arabica L.). Campinas, Universidade Estadual de Campinas. Tese de Doutorado.
Fahl JI, Carelli MLC, Vega J, Magalhães AC (1994) Nitrogen and irradiance levels affecting net photosynthesis and growth of young coffee plants. J. Hortic. Sci. 69:161-169.

Farquhar GD, O’Leary MH, Berry JA. (1982) On the relationship between carbon isotope discrimination and intercellular carbon dioxide concentration in leaves. Aust. J. Plant Physiol. 9:121-137.

Farquhar GD, Ehleringer JR, Hubick KT (1989) Carbon isotope discrimination and photosynthesis. Ann. Rev. Plant Physiol. Plant Mol. Biol. 40:503-537.

Guedes MEM, Nunes MA (1978) Trocas gasosas em folhas de cafeeiro infectadas por Hemileia vastratix Berk. \& Br. Garcia de Orta 5:31-36.

Hatch MD (1987) $\mathrm{C}_{4}$ photosynthesis: a unique blend of modified biochemistry, anatomy and ultrastructure. Biochim. Biophys. Acta 895:81-106.

Holaday AS, Lee KW, Chollet R (1984) $\mathrm{C}_{3}-\mathrm{C}_{4}$ intermediate species in the genus Flaveria: leaf anatomy, ultrastructure, and the effect of $\mathrm{O}_{2}$ on the $\mathrm{CO}_{2}$ compensation concentration. Planta 160:25-32.

Johansen, DA (1940) Plant Microtechinique. Mc Grow-Hill, New York.

Larcher, W (1995) Physiological Plant Ecology. SpringerVerlag, Berlin.

Lopes Y, Riano N, Mosquera P, Arcila J (2000) Activities of phosphoenolpyruvate carboxilase and ribulose-1,5bisphosphate carboxylase/oxygenase in leaves and fruit pericarp tissue of different coffee (Coffea sp) genotypes. Photosynthetica 38:215-220.

Meinzer FC, Goldstein G, Grantz DA (1990) Carbon isotope discrimination in coffee genotypes grown under limited water supply. Plant Physiol. 92:30-135.

Nelson T, Langdale JA (1992) Developmental genetics of $\mathrm{C}_{4}$ photosynthesis. Annu.Rev. Plant Physiol. Mol. Biol. 43:25-47.

Nunes MA, Brumby D, Davies DD (1973) Estudo comparativo do metabolismo fotossintético em folhas de cana-de-açúcar. Garcia de Orta 1:1-14.

Ramalho JC, Pons TL, Groeneveld HW, Azinheira HG, Nunes MA (2000) Photosynthetic acclimation to high light conditions in mature leaves of Coffea arabica L.: role of xanthophylls, quenching mechanisms and nitrogen nutrition. Aust. J. Plant Physiol. 27:43-51.

Sondahl MR, Crocomo OJ, Sodek L (1976) Measurements of ${ }^{14} \mathrm{C}$ incorporation by illuminated intact leaves of coffee plants from gas mixtures containing ${ }^{14} \mathrm{CO}_{2}$. J. Exp. Bot. 27:1187-1195.

Swerhone GDW, Hobson KA, van Kessel C, Boutton TW (1991) An economical method for the preparation of plant and animal tissue for $\delta^{13} \mathrm{C}$ analysis. Commun. Soil Sci. Plant Anal. 22:177-190.

Voltan RBQ, Fahl JI, Carelli MLC (1992) Variação na anatomia foliar de cafeeiros submetidos a diferentes intensidades luminosas. Rev. Bras. Fisiol. Veg. 4:99-105.

Yamaguchi T, Friend DJ (1979) Effect of leaf age and irradiance on photosynthesis of Coffea arabica. Photosynthetica 13:271-278. 